\title{
Air Transport Development in the Middle East: A Review of the Process of Liberalisation and its I mpact
}

\author{
John F. O'Connell ${ }^{1, a, *}$ and George Williams ${ }^{1, b}$ \\ ${ }^{1}$ The Department of Air Transport, Cranfield University, Bedford, MK43 OAL, UK
}

\begin{abstract}
The air transport market in the Middle East is undergoing a rapid transformation as passenger traffic is beginning to surge through the area. This paper examines the impact that deregulation is having on the region, including the growth of low cost carriers. It establishes that the region is working towards a pan-regional agreement on liberalisation under the leadership of the Arab Civil Aviation Commission.
\end{abstract}

KEYWORDS: Middle East, Arab Air Carriers Organization, Liberalisation, Pan-regional agreement on liberalisation, Arab Civil Aviation Commission, Low Cost Carriers.

\section{I NTRODUCTION}

According to the World Tourism Organisation, the Middle East is comprised of Bahrain, Egypt, Iraq, Jordan, Kuwait, Lebanon, Libya, Oman, Palestine, Qatar, Saudi Arabia, Syria, the UAE and Yemen, with Israel placed in the East Mediterranean Europe category (World Tourism Organisation, 2005). The collective population of these states was approximately 179 million in 2007, which constitutes just 3 per cent of the world's population (IMF, 2007). The six main countries that are classified as the engines of growth in the Middle East are Bahrain, Kuwait, Oman, Qatar, Saudi Arabia and the United Arab Emirates (UAE), and are collectively known as

\footnotetext{
${ }^{a}$ Dr John (Frankie) O'Connell is a lecturer in Airline Management at the Air Transport Department at Cranfield University where he specialises in airline strategy and marketing. He travels extensively to the world's airlines where he instructs airlines on strategy, management, branding, distribution; strategy, cost reduction; alliances; low cost carriers; deregulation; trends and customer service.

* Corresponding author. E-mail: frankie.oconnell@cranfield.ac.uk, phone: +44(0) 1234754247

${ }^{\mathrm{b}}$ Dr. George Williams was until September 2009 Reader in Airline Economics at Cranfield Uiversity. With an academic background in Transport Economics, he has extensive international lecturing and consultancy experiences and has written two books and over 50 papers and research reports all exploring the impact of deregulation on the airline industry.
} 
the GCC (Gulf Cooperation Council) countries. There are 24 member airlines $^{c}$ associated with the Arab Air Carriers Organization (AACO) as the assembly encompasses all the Arab nations, stretching from the Persian Gulf right across Northern Africa to Morocco - a distance of some $6,450 \mathrm{kms}$.

The Middle East has long been seen as a geo-economic and geo-political epicentre of the world because of its vast reserves of hydrocarbons, while at the same time the region has been in a near constant state of conflict, keeping it under the spotlight of international attention. However, over recent years, there has been a tectonic shift in the global air transport market primarily because of the rise of the Middle East carriers, and in particular Arabian Gulf based airlines, which are beginning to impact the global airline industry. IATA data for 2007 highlighted that the growth in Middle East Revenue Passenger Kilometre (RPK) had surged to $18.1 \%$ - more than twice that of Africa which recorded the second highest growth rate.

This paper provides a brief overview of the Middle East's air transport market. It then describes the regulatory transformation that is beginning to penetrate the region and how low cost carriers are circumnavigating the regulatory obstacles and gaining a foothold in the marketplace. The study concludes with an analysis of a pan-regional agreement on liberalisation of the Middle East and it is compared to the EU third package. This paper fills a void in the existing literature regarding the deregulation of the Middle East air transport market.

\section{THE MI DDLE EAST'S RAPIDLY DEVELOPI NG AVI ATION MARKET}

ICAO (2007) calculated that the Middle East air transport market constitutes a mere $4.5 \%$ of the world market. However, its passenger traffic is heavily skewed towards international traffic of which it has a $7 \%$ share. There were approximately 79 million passengers transported by the 24 member airlines of the Arab Air Carriers Organisation (AACO) in 2007 (AACO, 2007). Non-AACO airlines transported an additional 46 million passengers to the Middle East and North Africa in 2007. Thus, the total air transport market stood at around 125 million passengers,

\footnotetext{
${ }^{\mathrm{c}}$ The 24 members of the Arab Air Carriers Organization (AACO) are Afriqiyah, Air Algerie, Air Arabia, Air Cairo, Egyptair, Emirates, Etihad, Gulf Air, Iraqi Airways, Gulf Air, Kuwait Airways, Libyan Airlines, Middle East Airlines, Oman Air, Palestine Airlines, Qatar Airways, Royal Air Maroc, Royal Jordanian, Saudi Arabian Airlines, Sudan Airways, Syrian Arab Airlines, Trans Mediterranean, Tunis Air and Yemenia.
} 
with a high concentration of the traffic centred in the Arabian Gulf states. The Middle East carriers also transported around 2.2 million tones of cargo in 2007, with Emirates responsible for over $45 \%$ of this freight (Air Cargo World, 2006). Figure 1 shows that the passenger traffic and cargo tonnage at Middle East airports increased by $120 \%$ and $110 \%$ respectively from 1998 to 2007. Steep increases in traffic were recorded from 2003 onwards, largely attributed to the extra capacity being added by Emirates, Qatar Airways and Etihad.

Figure 1 - Growth in Passenger and Cargo Traffic, and Aircraft Movements at Middle East Airports: 1998 - 2007

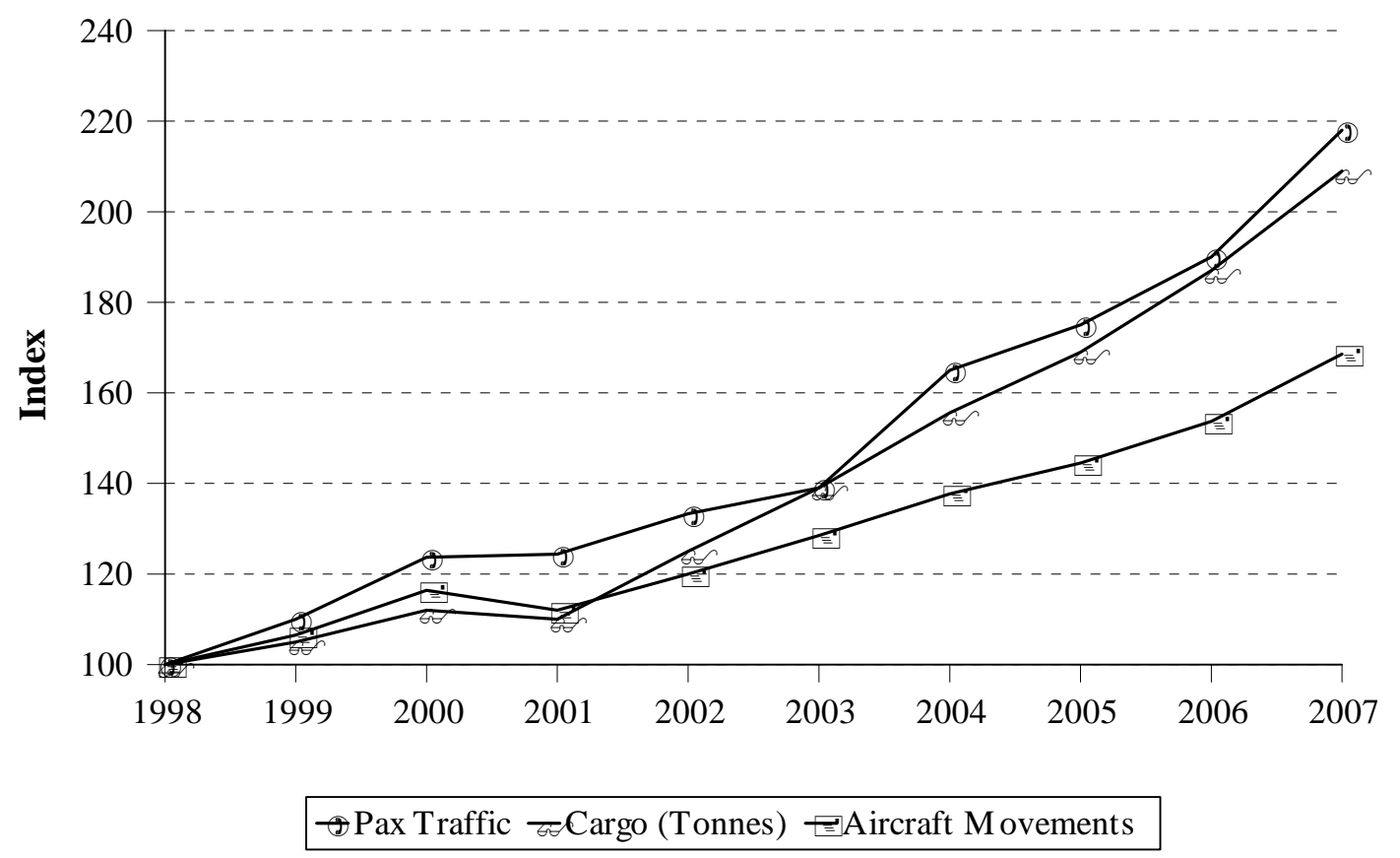

Sources: Arab Air Carriers Organization, Airports Council International

In 1988, the Arab carriers had a fleet of less than 150 aircraft with an average capacity of 170 seats, but by 2007 the fleet had expanded to more than 600 with an average capacity of 210 seats. Figure 2 shows that the narrowbody fleet was relatively unchanged from 2002 to 2007, while the number of widebody aircraft increased by $50 \%$. The Boeing General Market Outlook (2007) indicated that around 39\% of the world's fleet is composed of twin-aisle aircraft, with a further $4 \%$ composed of aircraft that are the size of a 747 or larger. However, the Middle East market is highly unique as around $57 \%$ of the aircraft in active service are widebodies. The 24 
member carriers of AACO have around 800 aircraft on order, which is approximately equivalent to the combined fleets of Air France, British Airways, Cathay Pacific, Iberia and Singapore Airlines. A large proportion of the fleet that is on order by Middle East carriers is destined for Emirates, Qatar Airways and Etihad Airways. This represents a huge threat to European and Asian carriers as these three Arabian Gulf carriers will utilise their sixth freedom traffic rights to channel large volumes of traffic from spoke cites in Asia, Africa, Europe, Africa and the Americas through their respective hubs (i.e. Dubai, Doha and Abu Dhabi).

Figure 2 - Active fleet within the Middle East 2002 - 2007 and the backlog of aircraft on order

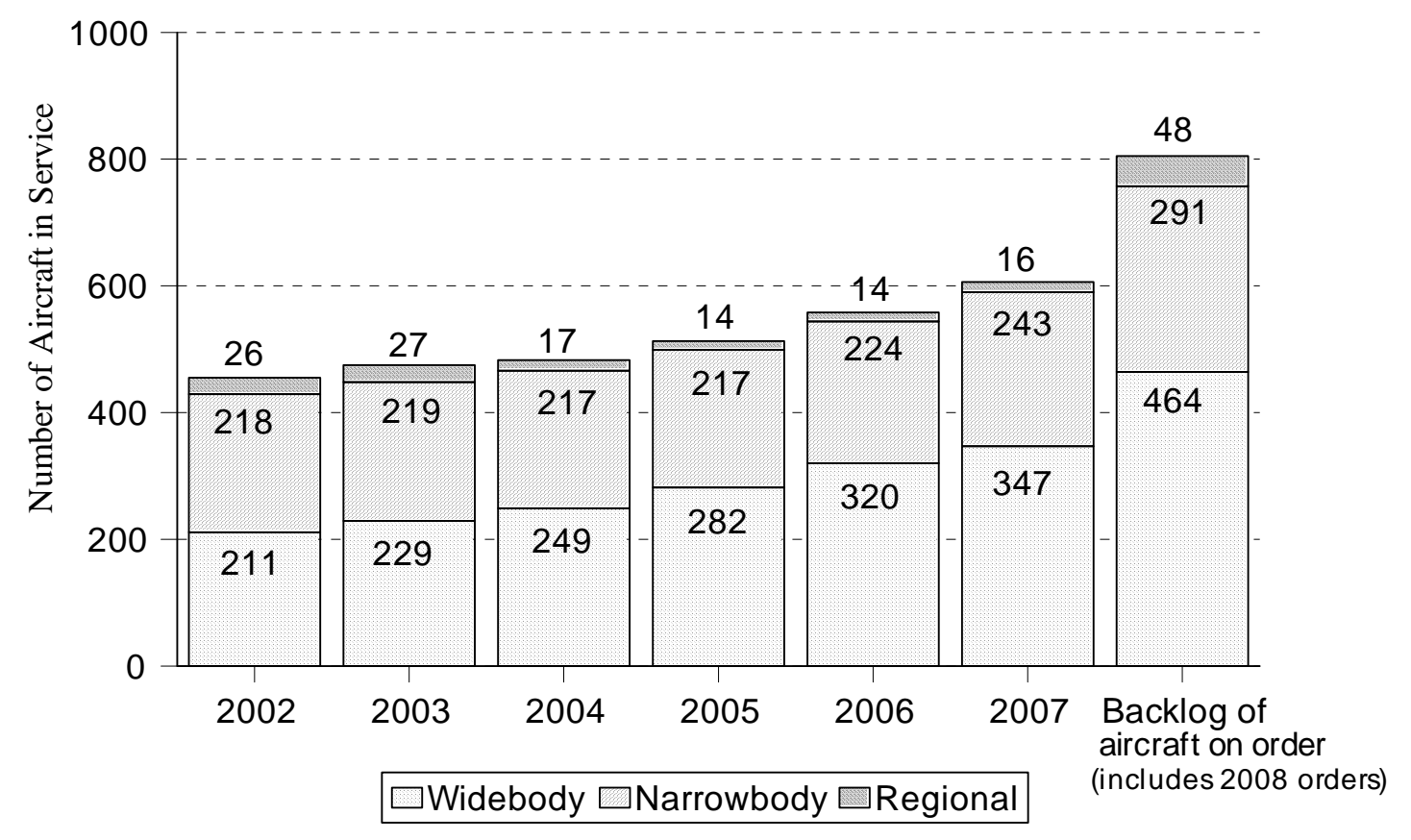

Sources: ACAS, Arab Air Carriers Organization

Table 1 below outlines the breakdown of airline traffic between the Middle East and the rest of the world from 1990 to 2007, and provides a forecast for 2027. It shows that the Middle East to Europe market is the region's most important sector, as it has the highest yield and is less competitive, because the European airlines schedule a large chunk of their long-haul capacity 
Table 1 - Traffic growth (billions of RPKs) between the Middle East and the rest of the world 1990 - 2027

\begin{tabular}{|c|c|c|c|c|c|c|c|c|c|c|c|c|c|c|c|}
\hline $\begin{array}{c}\text { Middle East } \\
\text { to: }\end{array}$ & 1990 & 1995 & 2000 & 2001 & 2002 & 2003 & 2004 & 2005 & 2006 & 2007 & $2027 \mathrm{~F}$ & $\begin{array}{l}\% \\
\text { change } \\
1990- \\
1995\end{array}$ & $\begin{array}{l}\% \\
\text { change } \\
1995- \\
2000\end{array}$ & $\begin{array}{l}\% \\
\text { change } \\
2000- \\
2007\end{array}$ & $\begin{array}{l}\text { \% } \\
\text { change } \\
2007- \\
2027\end{array}$ \\
\hline Africa & 7.4 & 6.5 & 9.8 & 10.6 & 13.2 & 13.9 & 13.9 & 16.4 & 17.9 & 19.8 & 64.0 & $-12.2 \%$ & $50.7 \%$ & $102.0 \%$ & $223.4 \%$ \\
\hline North America & 6.6 & 10.3 & 16.1 & 12.0 & 10.4 & 9.6 & 12.6 & 14.4 & 19.6 & 29.9 & 94.2 & $56.6 \%$ & $56.3 \%$ & $85.7 \%$ & $215.0 \%$ \\
\hline Middle East & 19.4 & 20.7 & 27.8 & 27.1 & 27.5 & 28.0 & 32.0 & 34.0 & 36.6 & 39.3 & 119.4 & $6.7 \%$ & $34.3 \%$ & $41.3 \%$ & $203.8 \%$ \\
\hline S.E. Asia & 11.0 & 20.6 & 24.0 & 22.9 & 24.0 & 26.4 & 29.2 & 33.3 & 38.3 & 44.8 & 127.2 & $87.3 \%$ & $16.5 \%$ & $86.6 \%$ & $183.9 \%$ \\
\hline India/Pakistan & 16.6 & 23.2 & 29.4 & 29.9 & 31.1 & 33.8 & 35.6 & 38.3 & 44.1 & 48.5 & 155.2 & $39.8 \%$ & $26.7 \%$ & $64.9 \%$ & $220.0 \%$ \\
\hline Europe & 41.5 & 44.9 & 65.0 & 59.8 & 58.6 & 58.9 & 67.7 & 74.1 & 88.4 & 104.6 & 274.6 & $8.2 \%$ & $44.7 \%$ & $60.9 \%$ & $162.5 \%$ \\
\hline
\end{tabular}

Source: Boeing Current Market Outlook 2007 and 2008 
for the North Atlantic market, thus creating an opportunity for the Middle East based carriers. In 2007, Europe accounted for $36 \%$ of the Arab carriers' RPKs which is double that of its next largest market, the Indian subcontinent, closely followed by South East Asia. In essence, all regions between the Middle East and the rest of the world have grown substantially since the early 1990s. Asia is an important component of the master-plan of the Middle East based carriers, as the region has so many cities with very large population catchment areas, which can be connected via hubs in the Middle East to Europe, Africa, India and the East coast of North America. Traffic from Asia has grown by around $86 \%$ from 2000 to 2007 and is forecast to increase significantly.

The Middle East based carriers have capitalised on Africa's financially weak and under-funded airlines, as RPKs have grown by over 100\% from 2000 to 2007 and Boeing estimates that these market pairs will register the highest growth rate over any of the other regions in the next two decades. They have also taken advantage of the underperforming state owned airlines of India and Pakistan, and from the rapid evolution of their deregulated international markets, as traffic is forecast to grow by around $220 \%$ over the next twenty years. Traffic between North America and the Middle East fell by around 40\% from 2000 to 2003, primarily because of 9/11 and the conflicts in Afghanistan and Iraq. However, it recovered quickly and is forecast to grow by $215 \%$ by 2027 . Only a few of AACO members offer services to North America and these include Egyptair, Emirates, Etihad, Kuwait Airways, Qatar Airways, Royal Air Maroc, Royal Jordanian Airlines and Saudi Arabian Airlines.

Panariello (2007) calculated that the Middle East based airlines earned around $\$ 20.6$ billion in revenues in 2006, 21\% higher than a year earlier, while the average operating margin registered just 3.9\%. The Middle East based airlines as a whole (excluding Emirates) were expected to deliver around $\$ 200 \mathrm{~m}$ in profit for 2008 , indicating widespread losses among a large number of flag carriers (Bisignani, 2008). 


\section{DEREGULATI ON IN THE MI DDLE EAST}

For decades, the Middle East air transport system has been heavily regulated. Negotiation of traffic rights is conducted within a bilateral system, with widely divergent levels of liberalisation existing within the region. Feiler and Goodovitch (1994) pointed out that the Middle East's air transport industry had stagnated because of its over-reliance on the oil industry, low levels of intra-regional trade and the institutionalised protection of its national carriers. Constraints in the allocation of traffic rights have posed a substantial barrier to the growth of new carriers. The region's first low cost carrier, Air Arabia, is for example only allowed to operate less than a daily service on the majority of its routes. Kaminski-Morrow (2006) reported that this new entrant carrier could expand its services five-fold if a pan-regional Open Aviation Area existed.

However, over recent years there has been a gradual progression towards liberalisation in the domestic, intra-regional and international markets of the Middle East. Domestic travel represents a very small proportion of total air traffic in most Middle East countries, with the exception of Saudi Arabia (around four times the size of France) and to a lesser extent Egypt. All flag carriers in their respective states have until recently fully controlled their domestic markets. Table 2 shows that domestic traffic in the Middle East states has been contracting except for Saudi Arabia and Egypt, while international traffic has been expanding rapidly despite the regulatory restrictions that are in place. Egypt has a large domestic air transport network and is the region's most populous state (around 80 million people). However, its regulatory regime is two-sided as Cairo remains closed and designated national carriers must operate in accordance with capacity controlled bilateral agreements, while all other airports have unrestricted access. This strategy has allowed Egyptair to hold on to $45 \%$ of the international traffic and retain a dominant position within the domestic market, as all feeder traffic from the airline's Star partners is carried between Cairo and other domestic points.

By contrast, the intra-regional and international markets are strikingly different. Services to the US, for example, operate under very liberal open skies agreements, but for intra-Arab routes the skies have been relatively closed. The Arab countries that have signed open skies agreements with the US include: Jordan (1996), UAE (1999), Bahrain (1999), Qatar (1999), Oman (2001) and Kuwait (2007). The open skies policies between the US and these Arab nations have acted as both a building block and a catalyst for changing the existing regulatory 
regime covering the intra-regional markets of the Middle East. This initial wave of liberalisation triggered the UAE, Bahrain ${ }^{4}$, Kuwait, Oman and Lebanon to expand their open skies policies and allow foreign and newly established carriers the right to operate unlimited services into their territories.

Table 2 - Domestic traffic trends in the larger Middle East countries

\begin{tabular}{|l|c|l|l|l||c|c|}
\cline { 2 - 6 } & \multicolumn{2}{c|}{1990} & \multicolumn{2}{c||}{2006} & $\mathbf{1 9 9 0 - 2 0 0 6}$ & $\mathbf{1 9 9 0 - 2 0 0 6}$ \\
\cline { 2 - 7 } & $\begin{array}{l}\text { Domestic } \\
\text { Passenger } \\
\text { Kilometres } \\
\text { (millions) }\end{array}$ & $\begin{array}{l}\text { Total } \\
\text { Passenger } \\
\text { Kilometres } \\
\text { (millions) }\end{array}$ & $\begin{array}{l}\text { Domestic } \\
\text { Passenger } \\
\text { Kilometres } \\
\text { (millions) }\end{array}$ & $\begin{array}{l}\text { Total } \\
\text { Passenger } \\
\text { Kilometres } \\
\text { (millions) }\end{array}$ & $\begin{array}{c}\% \\
\text { increase/decrease } \\
\text { of Domestic } \\
\text { Passenger km }\end{array}$ & $\begin{array}{c}\text { of Total } \\
\text { increase } \\
\text { Passenger km }\end{array}$ \\
\hline \hline $\begin{array}{l}\text { Saudi } \\
\text { Arabia }\end{array}$ & 5,435 & 15,440 & 8,769 & 25,314 & $62 \%$ & $64 \%$ \\
\hline Egypt & 430 & 4,430 & 635 & 10,556 & $48 \%$ & $138 \%$ \\
\hline Jordan & 14 & 3,540 & 13 & 5,589 & $-7 \%$ & $58 \%$ \\
\hline Syria & 52 & 1,135 & 29 & 2,340 & $-44 \%$ & $106 \%$ \\
\hline Yemen & 135 & 608 & 101 & 3,035 & $-25 \%$ & $400 \%$ \\
\hline
\end{tabular}

Sources: Feiler and Goodovitch, 1994 and ICAO 2007

\subsection{THE EMERGENCE OF LOW COST CARRIERS IN THE MIDDLE EAST}

In a similar manner to what transpired in Europe post-deregulation, low cost carriers have emerged to take advantage of liberalisation. In 2003, Air Arabia became the region's first budget carrier, operating out of Sharjah International airport in the UAE. By 2007, it was carrying 2.7 million passengers across the Middle East and to neighbouring states using 8 A320s, and accounting for $60 \%$ of Sharjah's traffic. The airline broke even in its first year of operation and has remained profitable ever since. Sine then it has been progressively reducing its break-even load factor to achieve a level of $63 \%$ by early 2008 , while at the same time

\footnotetext{
${ }^{4}$ Bahrain has 69 air services agreements with other governments, 20 of which are based on the 'Open Skies' principles and foundations (Bahrain International Airport, 2007).
} 
raising its load factor to $85 \%$ over the same period (Air Arabia, 2008). However, regulatory constraints by other countries within the Middle East have forced the carrier to operate with very low frequencies ( 3 to 4 times weekly), and to compensate for this it has had to expand its operations to serve 40 destinations in 20 countries - with the exceptions of Bahrain, Alexandria (Egypt) and Kuwait that are operated double daily as these states have open skies. OAG analysis reveals that around $27 \%$ of its seat capacity is used to serve the Arabian Gulf states, with a further $15 \%$ and $10 \%$ dedicated to other Arab and North African countries respectively.

To overcome these restrictions, Air Arabia has replicated the strategies of Air Asia and Tiger Airways by developing cross border ownership and management joint-ventures in Morocco and Nepal, setting up hubs in Casablanca and Kathmandu in the process. Low cost carriers often set up bases in nearby countries as their brand awareness becomes more established. However, Air Arabia has decided against this strategy, which may significantly impact its cost base as it must now invest large sums of capital into marketing programs in order to compete against well established brands. Its Moroccan partnership with Regional Air Lines will allow it to capitalise on the immense potential between North Africa and Southern Europe, as Morocco is the first North African country to establish an open skies agreement with the EU. Air Arabia ordered 10 A320s in late 2008 which are all earmarked for its hub at Casablanca. However, its joint venture in Nepal in conjunction with Flyyeti was suspended shortly after its inauguration, as a result of political and economic uncertainties. This strategy clearly demonstrates the ingenuity of Air Arabia in overcoming regulatory hurdles. The carrier's success and the open skies policy of the UAE have provided the catalyst for other low cost carriers to emerge, and by mid 2008 there were five such airlines ${ }^{5}$ operating in the Middle East, which had captured around $4 \%$ of the market (Centre for Asia Pacific Aviation, 2008) and secured $12 \%$ of all the departures from the UAE (Sobie, May 2008).

The open skies arrangement in Kuwait allowed a Kuwaiti low cost carrier, Jazerra Airways, to commence operations in late 2005 and compete with Kuwait Airways. This second budget carrier operates A320s with a two-class seating configuration (36 business and 129 economy), and within two years of commencing operations it had transported 1.2 million passengers to 22 cities. During this time, it increased traffic between Kuwait and Alexandria by $35.6 \%$, Kuwait

\footnotetext{
${ }^{5}$ Air Arabia, Jazeera, NAS Air, Sama and Bahrain Air.
} 
and Amman by $19 \%$, Kuwait and Beirut by $31 \%$, and Kuwait and Damascus by $35 \%$. By the end of 2007, Jazeera Airways had captured $11 \%$ of the Kuwait market (Aviation Business, 2006; Sobie, February 2008). Consistent with the strategies pursued by low cost carriers in the liberated markets of Europe, Jazerra Airways created a second hub in Dubai. Sobie (2007) indicates that the UAE, Kuwait and Oman have already fully opened their skies to low cost carriers, while Syria and Jordan may follow suit as the low-fare services benefits both the economy and population. Fanek (2007) reported that open skies could be critical to Jordan ${ }^{6}$, as tourism has the potential to produce up to $10 \%$ of Jordan's GDP, up from today's $4 \%$. The Middle East low cost carriers appear to be the driving force behind moves to deregulate intraregionally.

Saudi Arabia has had one of the most restricted air transport policies in the world, giving Saudi Arabian Airlines a monopoly in its domestic market for almost 60 years. However, there has now been a major shift in the regulatory system with the country transitioning from a protectionist state to a more liberal one. It recently granted operating licences ${ }^{7}$ to two new entrant low cost carriers - Sama (Dammam based) and Nas Air (Riyadh based). ICAO (2007) data indicated that almost $35 \%$ of Saudi Arabian Airlines total passenger kilometres was domestic traffic, around 2.4 million passengers per annum being carried between the country's two largest cities of Riyadh and Jeddah. In 2008, Sama and Nas Air were operating 22 and 28 weekly flights respectively between the two cities, while the flag carrier operated around 110 weekly services. Sobie (2007) expects passenger levels to soar to 4 million because of the competition $^{8}$. In early 2008, the Saudi Government liberalised international services by allowing Sama to operate 19 international routes from the three main Saudi airports to Egypt, Jordan, Lebanon, Syria and the UAE, however it retained a restriction on the number of frequencies only allowing the carrier to operate on these routes once or twice a week. OAG analysis reveals that Sama had captured over 3\% of the Saudi Arabian international market by mid 2008.

\footnotetext{
${ }^{6}$ There are three commercial airports in Jordan (two of which are located in Amman). Aqaba airport is a 45 minute flight from Amman and is a tourist destination that is located beside the Red Sea. The latter adheres to a full 'Open Skies’ policy, while the airports in Amman remain closed.

${ }^{7}$ The operating conditions imposed on these carriers include mandatory flying of some public service obligation routes and respecting fare caps.

${ }^{8}$ Saudi Arabian Airlines charges the maximum fare permitted (Government-set price cap) of \$72 on the Riyadh to Jeddah route, while NAS Air charges on average \$33.
} 
The fifth low cost carrier in the region is Bahrain Air, which started operations in 2008 . It competes with Gulf Air on every short-haul route from Bahrain. OAG analysis reveals that it has already captured $7 \%$ of the Bahraini market, making it the second largest carrier after Gulf Air with $60 \%$ of the market. However, its business model does notfollow the classic LCC model, as it operates a two-class seating configuration, interlines cargo with KLM and code shares with Sama.

New entrant, FlyDubai, may well change low cost carrier dynamics within the Middle East - it is a subsidiary of Emirates and has ordered 54 Boeing 737-800 costing almost $\$ 5$ billion, with the option to convert to Boeing 737-900s. It is expected to commence operations in mid 2009 from Dubai's new airport, located less than 50kms away from Sharjah airport - the base of Air Arabia. It plans to start operations to 12 destinations with the aim of building a network of around 70 routes.

The region's flag carriers are strategically focused on the threat posed by the budget airlines, with Saudi Arabian Airlines and Etihad Airways both studying the option of setting up their own low cost subsidiaries, while Qatar Airways has stated that it would launch a budget carrier within 90 days if low cost carriers begin to significantly impact its home market (Air Transport Intelligence, April 2007; April 2008; July 2008).

\section{TOWARDS A PAN-REGI ONAL AGREEMENT ON LI BERALI SATION}

There are two patterns of liberalisation emerging in the Middle East. Firstly the GCC states are aiming to create a single market. Legislation passed in 2003, allowed goods to be moved between member states without being subjected to the usual customs duties and inspections. The integrated market would offer equal opportunities for all GCC citizens including the right to work in all government and private institutions in member states, buy and sell real estate and make other investments, move freely between the countries, and receive education and health benefits. Plans for a common currency between member states may become a reality by 2010 (Arab News, 2008). This type of integration is similar to what occurred to the European Union in the early 1990s and it may trigger an open skies policy to be formulated between the six 
members of the GCC states, however this is speculative but at the same time it could become a distinct possibility.

The second pattern of liberalisation that is emerging out of the Middle East is associated with a specific committee called the Arab Civil Aviation Commission ${ }^{9}$ (ACAC). This association is actively leading its members towards adopting an open skies policy as part of the Arab League's road map for the liberalisation of air transport. ${ }^{10}$ Pinkham (2004) stated that this document essentially provided the 'nucleus of a single aviation market' for the region. A significant step forward took place between 2004 and 2007 with the signing and subsequent ratification of a multilateral agreement on air transport liberalisation among Arab countries, including access to fifth freedom rights on a bilateral basis. Table 3 shows that J ordan, Lebanon, Palestine, Syria, Yemen and the UAE have now ratified the agreement, which is an important initiative that should trigger more competition and higher rates of intra-Middle East traffic growth. Other states which have signed the treaty, but have not yet ratified it include Algeria, Bahrain, Iraq, Egypt, Mauritania, Morocco, Oman, Somalia, Sudan and Tunisia. As adoption of this multilateral agreement increases, it will accelerate the process of change also at the bilateral level, with state policies increasingly being influenced by changes in the international marketplace (AACO, 2007). At the AACO 2008 AGM, its member airlines appealed to their respective governments to: investigate the optimisation of air routes by making them more direct; rethink taxation policies on airlines and airports; insist that privatised airports do not take advantage of their monopoly positions; and allow freer movement of people between Arab nations, as many still enforce strict visa rules. ACAC was also asked to look into permitting cross-border equity stakeholding of the Arab airlines, which could pave the way to reaching a single Arab air transport market, similar to that which the European Union had established (AACO, 2008). However, the lack of a pan-Arab regulatory body to govern the ACAC presents a major challenge to the realisation of a multilateral regime.

\footnotetext{
${ }^{9}$ ACAC has 16 Member States: Bahrain, Egypt, Iraq, Jordan, Lebanon, Libya, Morocco, Oman, Palestine, Qatar, Saudi Arabia, Sudan, Syria, Tunisia, United Arab Emirates and Yemen.

${ }^{10}$ Some African countries have multiple affiliations with different liberalisation programs both in Africa and with the Arab nations. Algeria, Egypt, Libya, Morocco, Sudan and Tunisia are affiliate members of ACAC and signatories to the Yamoussoukro II Declaration, which contains the terms for liberalising air transport across the entire African Continent. Egypt, Libya and Sudan are also members of ACAC and COMESA (Common Market for Eastern and Southern Africa).
} 
Table 3 - Signatory states to the ACAC Liberalisation Agreement (2008)

\begin{tabular}{|l||c|c|}
\hline Country & $\begin{array}{l}\text { Signed the ACAC } \\
\text { Agreement }\end{array}$ & $\begin{array}{l}\text { Ratified the ACAC } \\
\text { Agreement }\end{array}$ \\
\hline Algeria & Yes & No \\
\hline Bahrain & Yes & No \\
\hline Egypt & Yes & No \\
\hline Iraq & Yes & Yes \\
\hline Jordan & Yes & Yes \\
\hline Lebanon & Yes & No \\
\hline Mauritania & Yes & No \\
\hline Morocco & Yes & No \\
\hline Oman & Yes & Yes \\
\hline Palestine & Yes & No \\
\hline Somalia & Yes & No \\
\hline Sudan & Yes & Yes \\
\hline Syria & Yes & No \\
\hline Tunisia & Yes & Yes \\
\hline UAE & Yes & Yes \\
\hline Yemen & & \\
\hline & & Yes \\
\hline
\end{tabular}

Note: Those countries that are outlined in bold have both signed and ratified the treaty Source: Arab Civil Aviation Commission (ACAC)

The provisions of the agreement will provide the region with a new set of rules that closely resemble those embodied in the EU's Third Package. ACAC envisions that the Middle East will replicate the stepping-stone approach that was used in Europe as the way forward to introduce deregulation into the region. The objectives of the ACAC liberalisation agreement involve the establishment of a 'vast Arab free trade zone' to foster regional and international economic development, thereby freeing the intra-regional movement of passengers, goods and capital (ACAC, 2004). In an intra-regional context, the terms of the agreement permit, with the exception of domestic cabotage, licensed carriers to access all markets within the region - 
without controls on the determination of capacity or tariffs - and allow cross-border ownership with the proviso that carriers have their ownership and effective control in the hands of nationals of states party to the agreement. Teffaha (2008) stated that Arab governments need to open up and adopt liberal air transport policies as they have reached a regulatory crossroad. Optimism with regard to a more liberalised operating environment is arguably high: a recent survey of 300 industry executives revealed that over two thirds of respondents viewed the easing of restrictions on aviation traffic rights by the region's governments as likely (Aviation Business, 2007). Nevertheless, the agreement in its current form contains significant weaknesses; these principally stem from an absence of an executive authority and pan regional framework to oversee and arbitrate in matters of competition. Whereas the EU single aviation market falls under the competition rules enshrined in Articles 81-89 of the Treaty of Rome, which forms the basis of the European Community, the OAA proposed by the ACAC agreement is conceived without equivalent binding legislation. Table 4 outlines the provisions of the agreement.

Table 4 - Provisions of the ACAC agreement compared with the EU Third Package

\begin{tabular}{|c|c|c|}
\hline Legislation & ACAC Agreement Pact & EU Council Regulation \\
\hline $\begin{array}{l}\text { Licensing } \\
\text { and } \\
\text { ownership } \\
\text { of airlines }\end{array}$ & $\begin{array}{l}\text { Section } \mathbf{3}, \mathbf{A r t i c l e ~} \mathbf{5} / \mathbf{2 a} \\
\text { Air transport operating licence to be } \\
\text { available to one or more carriers in each } \\
\text { Party State provided that 'The substantial } \\
\text { ownership and actual control of the } \\
\text { [airline] is under one or more Party } \\
\text { Countries or Citizens thereof and the } \\
\text { main head office of the Company } \\
\text { activities is located in one of the Party } \\
\text { Countries'. }\end{array}$ & $\begin{array}{l}\mathbf{2 4 0 7 / ~ 9 2 , ~ A r t i c l e ~ 4 / ~ 1 a ~ a n d ~} \mathbf{4 / 2} \\
\text { Air transport operating licence to be } \\
\text { granted by a Member State only if a } \\
\text { [carrier]'s: 'principal place of business } \\
\text { and...registered office is located in that } \\
\text { Member State', is 'owned and } \\
\text { continue[s] to be owned directly or } \\
\text { through majority ownership by Member } \\
\text { States and/or nationals of Member } \\
\text { States' and 'at all times be effectively } \\
\text { controlled by such States or such } \\
\text { nationals'. }\end{array}$ \\
\hline
\end{tabular}




\begin{tabular}{|c|c|c|}
\hline $\begin{array}{l}\text { Granting } \\
\text { of } \\
\text { Traffic } \\
\text { Rights }\end{array}$ & $\begin{array}{l}\text { Section 2, Article } \mathbf{2} \text { / a/ b/ c } \\
\text { Appointed carriers are granted the } \\
\text { following rights when operating } \\
\text { scheduled services between Party } \\
\text { Countries: 'The right to transit at any } \\
\text { territory of the other Party Countries' } \\
\text { territories'; 'the right to land at any } \\
\text { territory of the other Party Countries' } \\
\text { territories for non-commercial purposes'; } \\
\text { 'the right to load/ unload goods, } \\
\text { passengers and mail whether separately } \\
\text { or jointly to the Party Countries' } \\
\text { territories'. Cabotage rights are not } \\
\text { granted. }\end{array}$ & $\begin{array}{l}\mathbf{2 4 0 8 / 9 2 ~ A r t i c l e s ~} \mathbf{2 / 2 f} \text { and } \mathbf{3 /} \mathbf{1} \\
\text { Whereas under } 2 / 2 f \text {, 'traffic right' is } \\
\text { defined as 'right of an air carrier to } \\
\text { carry passengers, cargo and/or mail on } \\
\text { an air service between two Community } \\
\text { airports', under } 3 / 1 \text { 'Community air } \\
\text { carriers shall be permitted by the } \\
\text { Member State(s) concerned to exercise } \\
\text { traffic rights on routes within the } \\
\text { Community'. Cabotage rights are } \\
\text { granted. }\end{array}$ \\
\hline $\begin{array}{l}\text { Capacity } \\
\text { Controls }\end{array}$ & $\begin{array}{l}\text { Section } \mathbf{3} \text {, Article } \mathbf{7 /} \mathbf{1} \\
\text { Appointed air carriers 'may operate the } \\
\text { capacity and number of flights as they } \\
\text { may deem appropriate, and by any } \\
\text { aeroplane model to operate air services } \\
\text { among the Party Countries'. }\end{array}$ & $\begin{array}{l}\text { 2408/ 92, Article } \mathbf{1 0 / 1} \\
\text { 'Capacity limitations shall not apply to } \\
\text { air services covered by this Regulation' } \\
\text { with the exception of necessary } \\
\text { regulating of capacity within an airport } \\
\text { group (Article 8) or for environmental } \\
\text { reasons (Article 9). }\end{array}$ \\
\hline Tariffs & $\begin{array}{l}\text { Attachment } \mathbf{1} \text { / } \mathbf{1} \text { and } \mathbf{1} \text { / } \mathbf{4} \\
\text { Appointed carriers belonging to Party } \\
\text { Countries 'shall set the air transportation } \\
\text { tariffs on the basis of market commercial } \\
\text { considerations', 'none of the air } \\
\text { transportation tariffs among the Party } \\
\text { Countries requires the approval of the } \\
\text { Civil Aviation Authorities'. }{ }^{1}\end{array}$ & $\begin{array}{c}\text { 2409/ 92, Article 5/ } 1 \\
\text { 'Without prejudice to this Regulation, } \\
\text { Community air carriers shall freely set } \\
\text { air fares.' }\end{array}$ \\
\hline
\end{tabular}


1. Under the ACAC agreement (Section 3, Article 8/2), notification of fares must be made to the relevant Civil Aviation Authority no less than thirty days prior to fares being made available this contrasts with the provisions of 2409/92, Article 5/2 which stipulates that no more than 24 hours notice before fares come into effect need be provided to the relevant Civil Aviation Authority.

Sources: ACAC 2004; European Council 1992a; European Council 1992b; European Council 1992c; Abuel-Ealeh (2007).

The Arabesk Alliance provides evidence that this ACAC multilateral agreement between Arab member states has the potential to succeed. A number of carriers have worked together and created the first pan-Arab airline alliance, which comprises EgyptAir, Etihad Airways, Gulf Air, Middle East Airlines, Royal Jordanian Airlines, Saudi Arabian Airlines, Syrian Arab Airlines, Tunisair and Yemenia. The alliance is aimed at reducing the duplication of capacity, linking networks and destinations, generating market demand through improved customer connectivity, maximizing capacity utilization through route sharing and rationalization, and achieving efficiency through cooperation. However, it is too early to forecast the potential impact of this pan-regional alliance whose primary weakness is its inadequate global reach.

\section{CONCLUDI NG COMMENTS}

The spotlight of international attention has long been focused on the Middle East because of its vast reservoirs of petrochemicals and its tumultuous history of conflict. Its once dormant aviation industry has been transformed into a thriving industry. The region's carriers have orders for around 800 aircraft and this president is set the change the dynamics of the global air transport industry.

The Middle East remains regulated but this process is slowly evolving as low cost carriers are pushing the regulatory barriers, similar to what has occurred in Asia. The low cost carriers have acquired around $4 \%$ of the Middle East market and the open skies policy adopted by the United Arab Emirates has allowed these carriers to flourish by opening bases, which has allowed them to capture a sizable chunk of the UAE market. The rapid success of these new entrant carriers in the region demonstrate once again that the developments that we have come to expect from deregulation can be replicated anywhere in the world. There are two patterns of liberalisation 
emerging in the Middle East. Firstly the six GCC states which are classified as the engines of the Middle East are in the process of constructing an integrated economic and social policy with the aim of creating a single market. This in turn may trigger an open skies policy between these states. Secondly, a liberalisation process is underway that engages 16 member states under the auspices of ACAC, which also encapsulates some of the GCC states. It closely replicates the blueprint of the EUs third package, which transformed Europe's bilateral agreements between member states into an open skies platform. The agreement will allow carrier access to all markets without any restrictions on capacity or tariffs, while at the same time permitting cross border ownership. The sole restriction of the agreement is that the rules that govern cabotage will apply. All this implies that the Middle East wants regulatory change and the low cost carriers may very well provide the stimulus to expedite this process.

\section{REFERENCES}

- AACO (2007), Arab Airlines Traffic Data, accessed at http://www. aaco.org/stats.asp

- AACO (2008), AACO 41st Annual General Meeting, Tunisia $22^{\text {nd }}$ October, accessed at http://www. aaco.org/pubnews. asp?id=1747\&lang=1

- Abuel-Ealeh, S. (2007), A study of the market for intra-regional air services in the Middle East, Unpublished MSc. thesis, Cranfield University.

- ACAC (2004), Liberalising air transportation among the Arab countries (Translation), Arab Civil Aviation Commission, Damascus.

- Air Arabia (2008), Air Arabia: Investor Presentation, accessed at

- www.airarabia.com/investor\% 20relations.html\#_InvestorsPresentation

- Air Cargo World (2006), Region Focus: The Middle East, November, p 8-10.

- Air Transport Intelligence (2007), Saudi Arabian said to be planning own low-cost airline, April $18^{\text {th }}$.

- Air Transport Intelligence (2008), Etihad considers branching into budget operations, $24^{\text {th }}$ April.

- Air Transport Intelligence (2008), F/2008: Qatar Airways prepared to retaliate to lowfare threat, $15^{\text {th }}$ July.

- Arab News (2008), GCC Agrees on Monetary Union but Signals Delay in Common Currency, $10^{\text {th }} \mathrm{June}$, accessed at $w w w$. arabnews. com $/$ page $=6 \&$ section $=0 \&$ article $=110727$ 
- Aviation Business (2006), Jazeera's Era, ITP Publication, Dubai UAE, December, p24-26.

- Aviation Business (2007), Low Cost Carriers, ITP Publication, Dubai UAE, March, p25.

- Bahrain International Airport (2007), Bahrain International Airport website, available at: http://www.caa.gov.bh/ (accessed December, 2007).

- Bisignani, G. (2008), AACO Annual General Meeting in Tunis - Remarks of Giovanni Bisignani, accessed at http://www.iata.org/pressroom/speeches/2008-10-22-01.htm.

- Boeing General Market Outlook (2007), How will you travel through life?, accessed at ww.boeing.com/commercial/cmo/pdf/Boeing_Current_Market_Outlook_2007.pdf.

- Centre for Asia Pacific Aviation (2008), LCCs and Start ups - FlyDubai, Monthly Essential Middle East, August, p 30.

- European Council (1992a), Council Regulation (EEC) No 2407/92 of 23 July 1992 on licensing of air carriers, Brussels.

- European Council (1992b), Council Regulation (EEC) No 2408/92 of 23 July 1992 on access for Community air carriers to intra-Community air routes, Brussels.

- European Council (1992c), Council Regulation (EEC) No 2409/92 of 23 July 1992 on fares and rates for air services, Brussels.

- Fanek, F.(2007), Tourism Contribution - 3\% of GDP, Monday's Economic Pulse, Jordan Times, $32^{\text {nd }}$ ed., Amman.

- Feiler, G., Goodovitch, T. (1994), Decline and growth, privatization and protectionism in the Middle East airline industry, Journal of Transport Geography, Vol. 2, No. 1, pp.5564.

- IMF (2007), International Monetary Fund - World Economic Outlook Database April 2007, available at: http://www.imf.org/external/pubs/ft/weo/2007/01/data/index.aspx (accessed J uly 2007).

- ICAO (2007), Airline Traffic Forecasts and Financial Trends - 2006 to 2008, (cir312 AT/133), January.

- ICAO (2007), International Civil Aviation Organisation Database, available at: http://www.icaodata.com/ (accessed July 2007).

- Kaminski-Morrow, D. (2006), Air Arabia pushes Open Skies, Airline Business, November, p 25.

- Panariello, A. (2007), Regional Highlights, Airline Business, August, p62-63.

- Pinkham, R. (2004), States of Play, Airline Business, December, p64-65. 
- Sobie, B. (2007), Arabian Pioneers, Airline Business, May, p46.

- Sobie, B. (2008), Kuwait opens the door, Airline Business, February, p18.

- Sobie, B. (2008), Dubai opts to take low-cost plunge, Airline Business, May, p24.

- Teffaha, A.W. (2008), Pan-Arab Liberalisation, Airline Business, January, p66.

- World Tourism Organisation (2005), Methodological Notes, World Tourism Organisation, Madrid. 